\title{
Influence of Variable Manganese and Silicon on the Nutrition, Sugar Production, and Enzyme Activity of Immature Sugarcane
}

\author{
G. Samuels and Alex G. Alexander 1
}

INTRODUCTION

Little is known about the function of silicon (Si) in the sugarcane plant. The fact that cane develops normally when only minute amounts of Si are available indicates that the large quantities usually absorbed are probably not necessary.

Sugarcane absorbs more Si than any other mineral element. Ayres (11) showed that a 12-month sugarcane crop accumulated in above-ground tissues the following nutrients expressed as pounds per acre: Silica $\left(\mathrm{SiO}_{2}\right)$ 725 , potash $\left(\mathrm{K}_{2} \mathrm{O}\right) 390$, nitrogen $(\mathrm{N}) 125$, and phosphate $\left(\mathrm{P}_{2} \mathrm{O}_{5}\right) 40$. Ballard (12) reported the following $\mathrm{SiO}_{2}$ percentages expressed on a dry-weight basis: Dry leaves, 2.6; green leaves, 1.8; nonmillable top, 0.28 ; dry-leaf millable cane, 0.20 ; and green-leaf millable cane, 0.15 .

Nearly all aerial tissues in plants retain siliceous skeletons, after the organic matter is destroyed, indicating the obvious structural role played by $\mathrm{Si}$. The Si present for the most part is opal, although some exists in the plant as alpha quartz (21). However, the role of Si in the nutritional physiology of the plant remains highly obscure.

Manganese ( $\mathrm{Mn})$ is known to be an essential element for plant growth. Most sugar-producing areas do not appear to have problems with $\mathrm{Mn}$ deficiency. Certain locations, such as the Pahola area in Hawaii and the organic soils of Florida, have shown Mn deficiencies and responses to $\mathrm{Mn}$ fertilization.

Some soils, however, contain excess amounts of soluble Mn. Acid, poorly drained clay soils subject to high rainfall often appear to have such large amounts of available $\mathrm{Mn}$ as to hinder plant growth. Clements (15) reported control of Mn toxicity in certain hydrol humic latosols in Hawaii and Puerto Rico by using large applications of lime or of calcium silicates. Reduction of $\mathrm{Mn}$ levels in sugarcane has also been accomplished in Mauritius by using large amounts of powdered basalts high in silica (32).

The recent interest in the role of $\mathrm{Si}$ for suppressing excessive $\mathrm{Mn}$ uptake has given stimulus to ascertain anew the possible role of $\mathrm{Si}$ in the nutrition and production of sugar in sugarcane. Of further interest is the fact that

${ }^{1}$ Agronomist and Plant Physiologist, respectively, Agricultural Experiment Station, Mayagüez Campus, University of Puerto Rico, Río Piedras, P. R.

2 Italic numbers in parentheses refer to Literature Cited, pp. 26-7. 
Mn has been found to activate invertases of sugarcane (5). Research was therefore undertaken at the Agricultural Experiment Station, University of Puerto Rico, in order to clarify interrelationships of Si and $\mathrm{Mn}$ in the nutrition, sugar production, and enzymology of sugarcane.

\section{MATERIALS AND METHODS}

\section{GROWTH AND SAMPLING OF PLANT MATERIALS}

One-eye cuttings of the variety M. 336 were planted in a fine quartz sand ("silica shot") on November 14, 1964, and all plants received a zero Mn nutrient solution ${ }^{3}$ until treatments were begun on December 16 . The sand was previously treated for 12 hours with $0.01 \mathrm{~N} \mathrm{HCl}$. After thorough leaching with tapwater, the sand was placed in glazed, 2-gallon containers and washed with 2 liters of distilled water. Ten to twelve PMA-treated cuttings $^{4}$ were planted in each container. After 30 days of growth, 45 of the most uniform containers were selected for treatment from an initial total of 80 .

Treatments consisted of $3 \mathrm{Mn}$ levels $(0,10$, and 100 p.p.m.) and $3 \mathrm{Si}$ levels $(0,50$, and 500 p.p.m.) supplied in a $3 \times 3$ factorial combination. Five replicates were maintained in a completely randomized greenhouse design. All containers were shifted in a rotation sequence, whereby each individual pot completed one tour of the greenhouse area in 7 days. Mn was supplied as the chelate EDTA-Na2 $\mathrm{Mn}$, and $\mathrm{Si}$ as the sodium salt $\left(\mathrm{Na}_{2} \mathrm{SiO}_{3}\right.$. $9 \mathrm{H}_{2} \mathrm{O}$ ). Ionic strength was balanced among feeding solutions with $\mathrm{NaCl}$. Nutrient solutions were prepared with A.C.S.-grade reagents in distilled water and supplied in 1-liter volumes on Tuesdays, Thursdays, and Saturdays. One liter of distilled water was given on alternate days.

All plants were harvested at 3 months of age. From each replicate, 4 of the most uniform plants were selected for sugar and enzyme assay. The remaining plants were weighed and composited for mineral analyses. Meristem tissues and leaves +1 to $+4^{5}$ were frozen in a mixture of Dry Ice and acetone. These were lyophilized, ground to pass a 60 -mesh screen, and stored in sealed sample jars at $-10^{\circ} \mathrm{C}$.

\section{LABORATORY ANALYSES}

$\mathrm{N}, \mathrm{P}$, and $\mathrm{K}$ analyses were conducted at the Station's Central Analytical Laboratory, using leaf and sheath samples prepared by the wet digestion

3 Nutrient concentrations, expressed as meq./liter, were provided as follows: $\mathrm{NO}_{3}, 10 ; \mathrm{P}_{2} \mathrm{O}_{5}, 6 ; \mathrm{K}, 5 ; \mathrm{Ca}, 3 ; \mathrm{Mg}, 2 ;$ and $\mathrm{SO}_{4}, 2$. Microelements, expressed as p.p.m. were supplied as follows: $\mathrm{B}, 0.05 ; \mathrm{Cu}, 0.02 ; \mathrm{Zn}, 0.05 ; \mathrm{Mo}, 0.01$, and $\mathrm{Fe}, 1.0$.

- Cuttings were immersed in a 0.25-percent solution of PMA (phenyl mercury acetate) and allowed to remain for 10 minutes.

5 The leaf nomenclature employed here is that of Kuijper (20) as described by Van Dillewijn (81), in which the highest leaf bearing a visible dewlap is designated +1 . 
procedure with $\mathrm{H}_{2} \mathrm{SO}_{4}$ and $\mathrm{H}_{2} \mathrm{O}_{2}$. Other elements were determined with dry-ashed samples.

Sugar and enzyme analyses were conducted with lyophilized leaf and meristem tissues, following extraction with distilled water at 20 to $22^{\circ} \mathrm{C}$. Tissue debris was removed by expression through four layers of cheesecloth. The suspensions were clarified by centrifuging for 10 minutes at 3,500 r.p.m. Aliquots of the supernatants were diluted with $0.25 \mathrm{~N} \mathrm{NaOH}$ and employed directly in sugar analyses.

Total ketoses were measured colorimetrically by the resorcinol method of Roe (26). The sucrose fraction was determined by the technique of Cardini et al. (13), in which fructose is destroyed by heating for 12 minutes at $100^{\circ} \mathrm{C}$. in $0.25 \mathrm{~N} \mathrm{NaOH}$. Fructose was estimated by subtracting sucrose values from those of total ketose.

Protein was precipitated from clarified extracts previously adjusted to pH 7.0 with $0.25 \mathrm{~N} \mathrm{NaOH}$. Sufficient solid $\left(\mathrm{NH}_{4}\right)_{2} \mathrm{SO}_{4}$ was added to achieve 95-percent saturation. Protein was removed by centrifuge, taken up in a minimum of distilled water, and refrigerated at $2^{\circ} \mathrm{C}$. Enzyme analyses were run within 48 hours using appropriate dilutions of the protein concontrate.

Phosphatase activity was assayed according to procedures already described (4), as was invertase (5), amylase (6), starch phosphorylase (7), polyphenol oxidase (10), and peroxidase (9). Protein content of the enzyme preparations was measured colorimetrically by the technique of Sutherland et al. (30), and enzyme action is herein recorded as specific activity (units per mg. of protein).

Numerical ratings were recorded for visual deficiency symptoms at the time of harvest. All data were subjected to statistical analysis of variance.

\section{RESULTS}

\section{FRESH WEIGHTS}

Silicon decreased the fresh weight of the cane plant markedly at the 500-p.p.m. level, at all levels of Mn (table 1). At all Si levels fresh weight was reduced as the $\mathrm{Mn}$ levels rose from 10 to 100 p.p.m. for plant tops.

Regression analyses showed that $\mathrm{Mn}$ treatments gave linear effects at the 5-percent level and quadratic effects at the 1-percent level. For $\mathrm{Si}$, the weight relationship was significant at the 1-percent level for both linear and quadratic data. There were no significant interactions of $\mathrm{Si}$ and $\mathrm{Mn}$ with regard to plant weight.

The absence of $\mathrm{Si}$ from the nutrient solution did not reduce yields to any appreciable extent. The omission of $\mathrm{Mn}$ from the nutrient solution did not reduce yields markedly at the 0 - and 50-p.p.m. Si level. In the absence of $\mathrm{Mn}$ in the nutrient solution a yield reduction was evident at the 500-p.p.m. 
Si level, but this was less likely due to Mn deficiency than to the excess of silicon which affected all $\mathrm{Mn}$ treatments at this level.

It appears that the addition of $\mathrm{Si}$ in no way enhanced cane growth at the 50-p.p.m. level and was significantly detrimental to growth at the 500-p.p.m. level. Root-weight response to the $\mathrm{Mn}$ and $\mathrm{Si}$ variables was quite similar to that obtained with the fresh weight of the above-ground portion of the sugarcane plant (table 1).

\section{MINERAL CONTENT}

\section{Manganese}

Leaf blades contained more $\mathrm{Mn}$ than sheaths at any given treatment level (table 2).

As anticipated, the Mn content of leaf blade and sheath rose with increasing $\mathrm{Mn}$ supply. Yet the Mn content of the plant was decreased with

TABLE 1.-Mean values for main effects and first-order interactions summarizing fresh weights (grams per plant) of immature sugarcane supplied with variable manganese and silicon in sand culture

\begin{tabular}{c|r|r|r|r|r|r|r|r}
\hline \multirow{3}{*}{$\mathrm{Si}$} & \multicolumn{4}{|c|}{ Fresh-weight tops } & \multicolumn{4}{|c}{ Fresh-weight roots } \\
\cline { 2 - 9 } & $\mathrm{Mn}_{\mathrm{0}}$ & $\mathrm{Mn}_{10}$ & $\mathrm{Mn}_{100}$ & Mean & $\mathrm{Mn}_{0}$ & $\mathrm{Mn}_{10}$ & $\mathrm{Mn}_{100}$ & $\mathrm{M}_{\text {ean }}$ \\
\hline 0 & 26.5 & 29.3 & 23.4 & 26.4 & 10.9 & 10.7 & 9.6 & 10.4 \\
50 & 28.3 & 27.0 & 20.0 & 25.1 & 10.7 & 10.9 & 11.7 & 11.1 \\
500 & 9.6 & 19.2 & 5.6 & 11.5 & 5.7 & 5.7 & 4.4 & 5.3 \\
\cline { 2 - 9 } Mean & 21.5 & 25.2 & 16.3 & & 9.1 & 9.1 & 8.6 & \\
\hline
\end{tabular}

increasing Si levels at all levels of $\mathrm{Mn}$. Despite the high amounts of $\mathrm{Mn}$ in the plant at the 10- and 100-p.p.m. Mn levels with zero $\mathrm{Si}$, there was no visual chlorosis due to Mn toxicity. Such Mn toxicity symptoms would appear as necrotic spots on the leaf blade, which in turn are commonly called "leaf-freckle". However, the high Mn treatments did show visual evidence of iron chlorosis.

When 50 p.p.m Si was introduced into the nutrient solution the $\mathrm{Mn}$ content failed to rise to the high values found at the zero Si level. When 500 p.p.m. of Si were provided, the $\mathrm{Mn}$ values were even further reduced. In fact, at the zero-Mn level, the addition of 50 and 500 p.p.m. Si reduced leaf-sheath $\mathrm{Mn}$ values below the 10-p.p.m. level cited as adequate (14) for sugarcane growth (table 2).

\section{Silicon}

The Si content of the leaf sheath was greater than the leaf blade at the zero-Mn level. At the other $\mathrm{Mn}$ levels, the leaf-blade and sheath values were quite similar. 
The zero-Si treatment gave $\mathrm{Si}$ values which are considered as low by field standards. Clements (15) cited sheath Si values of 0.34 to .45 percent as low, and the lowest value obtained in the present experiment was 0.19 percent, which is even below this range. Inasmuch as the plants were grown in quartz sand, it was not expected that the zero-Si treatment would yield plants with such low Si values.

The 50-p.p.m. Si treatment caused large increases in the $\mathrm{Si}$ values of the cane plant. With this treatment, silicon content of the sheath ranged above the 1.92-percent $\mathrm{Si}$ value considered by Clements (15) as high for

TABLE 2.-Mean values for main effects and first-order interactions, of manganese, silicon, and iron of leaf blade and shealh for immalure sugarcane supplied with variable manganese and silicon in sand culture

Leaf blade

\begin{tabular}{|c|c|c|c|c|c|c|c|c|c|c|c|c|}
\hline \multirow{2}{*}{$\mathbf{S i}$} & \multicolumn{4}{|c|}{ Mn (p.p.m.) } & \multicolumn{4}{|c|}{ Si (percent) } & \multicolumn{4}{|c|}{ Fe (p.p m.) } \\
\hline & $\mathbf{M n}_{0}$ & $\mathbf{M n}_{10}$ & $\mathbf{M n}_{100}$ & Mean & $\mathbf{M} \mathbf{n}_{0}$ & $\mathbf{M n}_{10}$ & $\mathbf{M n}_{100}$ & Mean & $\mathbf{M n}_{0}$ & $\mathrm{Mn}_{20}$ & $\mathrm{Mn}_{\mathbf{2 0 0}}$ & Mean \\
\hline 0 & 63 & 536 & 910 & 503 & 0.22 & 0.23 & 0.33 & $|0.26|$ & 207 & 113 & 96 & 139 \\
\hline 50 & 20 & 89 & 146 & 85 & 1.49 & 2.34 & 2.35 & 2.06 & 115 & 48 & 56 & 73 \\
\hline 500 & 24 & 56 & 217 & 99 & 2.12 & 2.99 & 3.72 & 2.94 & 712 & 93 & 26 & 277 \\
\hline Mean & 36 & 227 & 424 & & 1.27 & 1.85 & 2.13 & $|1.75|$ & 345 & 85 & 59 & \\
\hline
\end{tabular}

Leaf Sheath

\begin{tabular}{|c|c|c|c|c|c|c|c|c|c|c|c|c|}
\hline \multirow{2}{*}{$\mathbf{S i}$} & \multicolumn{4}{|c|}{ Mn (p p.m.) } & \multicolumn{4}{|c|}{ Si (percent) } & \multicolumn{4}{|c|}{$\mathrm{Fe}$ (p.p.m.) } \\
\hline & $\mathbf{M n}_{0}$ & $\mathbf{M n}_{10}$ & $\mathbf{M n}_{100}$ & Mean & $\mathbf{M} \mathbf{n}_{0}$ & $\mathbf{M n}_{10}$ & $\mathbf{M n}_{200}$ & Mean & $\mathbf{M} \mathbf{n}_{0}$ & $\mathbf{M n}_{10}$ & $\mathbf{M n}_{100}$ & Mean \\
\hline $\begin{array}{r}0 \\
50 \\
500\end{array}$ & $\begin{array}{r}35 \\
8 \\
6\end{array}$ & $\begin{array}{r}484 \\
66 \\
32\end{array}$ & $\begin{array}{r}666 \\
102 \\
55\end{array}$ & $\begin{array}{r}395 \\
59 \\
31\end{array}$ & $\begin{array}{l}0.28 \\
2.49 \\
2.79\end{array}$ & $\begin{array}{l}0.19 \\
2.47 \\
3.26\end{array}$ & $\begin{array}{l}0.22 \\
2.38 \\
3.31\end{array}$ & $\begin{array}{l}0.23 \\
2.45 \\
3.12\end{array}$ & $\begin{array}{r}31 \\
30 \\
239\end{array}$ & $\begin{array}{l}399 \\
649 \\
789\end{array}$ & $\begin{array}{r}1031 \\
284 \\
220\end{array}$ & $\begin{array}{l}487 \\
321 \\
416\end{array}$ \\
\hline Mean & 16 & 194 & 274 & & 1.85 & 1.97 & 1.97 & 1.93 & 100 & 612 & 512 & \\
\hline
\end{tabular}

sheaths in Hawaii. The 500-p.p.m. Si treatments increased Si levels in the leaf blade and sheath to over 3 percent at the 100-p.p.m. Mn level (table 2).

The Si content of the cane plant tended to increase as Mn levels were increased. This was much more apparent for the leaf blade than leaf sheath at the zero and 50-p.p.m. Si levels. However, at the 500-p.p.m. Si level, there was a well-defined increase in Si for both leaf blade and sheath as the Mn supplies were increased (table 2).

Iron

The leaf sheath contained more iron ( $\mathrm{Fe}$ ) than the leaf blade, with the exception of the zero-Mn treatment (table 2). The high Fe value in the 
leaf blade for the zero-Mn and 500-p.p.m Si treatment may have been due to fragments of $\mathrm{Fe}$ accidentally entering the samples during grinding; however, the leaf sheath also showed high values for this treatment.

The Fe content of the leaf blade tended to show an inverse relationship to increasing $\mathrm{Mn}$ levels. The depletion of $\mathrm{Fe}$ in the leaf blade with increasing Mn levels caused typical visual Fe-deficiency symptoms. These deficiencies were graded and are given in table 3. Iron deficiencies were most severe at the zero-Si treatment levels. Iron-deficiency symptoms diminished when $\mathrm{Si}$ was introduced. This was to be expected insofar as the $\mathrm{Si}$ treatments reduced the levels of $\mathrm{Mn}$ in the plant and thus restored $\mathrm{Fe} / \mathrm{Mn}$ ratios to normal.

Not readily explained is the fact that, in the leaf sheath, Fe values appeared to increase with increasing Mn levels rather than decrease as was

TABLE 3.-Ratings of visual iron chlorosis on the leaves of immature sugarcane supplied with variable manganese and silicon in sand culture

\begin{tabular}{c|c|c|c|c}
\hline \multirow{2}{*}{$\mathrm{Si}$} & \multicolumn{3}{|c|}{ Visual ratings of chlorosis } & \multirow{2}{*}{ Mean } \\
\cline { 2 - 4 } & $\mathrm{Mn}_{0}$ & $\mathrm{Mn}_{10}$ & $\mathrm{Mn}_{300}$ & \\
\hline \multirow{2}{*}{50} & 0 & 3.2 & 3.2 & 2.1 \\
500 & .4 & 1.6 & 2.2 & 1.4 \\
& .4 & 1.4 & 1.2 & 1.0 \\
\hline \multirow{2}{*}{ Mean } & 0.3 & 2.1 & 2.2 & \\
\hline
\end{tabular}

1 The visual ratings were as follows: $0=$ all leaves green; $1=$ occasional chlorotic leaf; 2 = leaves mostly green, a few chlorotic leaves; $3=$ most leaves chlorotic, $a$ few leaves green; $4=$ severe chlorosis on nearly all leaves.

found for the blade. Inasmuch as $\mathrm{Fe}$ is not a very mobile element, it may have accumulated in the leaf sheath when high $\mathrm{Mn}$ values present in the blade prevented its translocation. However, we have no direct evidence of this hypothesis.

\section{Other Elements}

The $\mathrm{N}$ content of the plant decreased with increasing Si levels, but showed no constant trend with varying $\mathrm{Mn}$ levels (table 4). Clements found that leaf $N$ was decreased significantly by increased silicate application in a low and moderately low silicate status soil in Hawaii (15).

There was a decrease in $\mathrm{P}$ in the plant with increasing Si levels. This appears to be contrary to the results obtained in field experiments in Hawaii with sugarcane (15), and with corn (19) and millet (17), where increasing silicate levels increased phosphate uptake in the plant.

The $\mathrm{P}$ content of the plant did not change appreciably with the varying levels. 
The $\mathbf{K}$ content of the plant did not show any particular trends resulting from variation in either $\mathrm{Mn}$ or Si levels (table 4).

Calcium values in the sugarcane plant dropped with increasing $\mathrm{Mn}$ and $\mathrm{Si}$ levels. The decrease of $\mathrm{Mn}$ with increasing $\mathrm{Ca}$ levels has been reported for sugarcane (14). Inasmuch as $\mathrm{Ca}$ was not a variable in this experiment, it was not possible to determine the effect of calcium levels on $\mathrm{Mn}$ as compared to Si.

The Mg content of the plant decreased gradually with increasing Si levels, but showed no relationships to Mn levels.

Increasing $\mathrm{Mn}$ and $\mathrm{Si}$ levels caused reductions in the $\mathrm{S}$ level of the cane plant (table 4).

TABLE 4.-Influence of varying manganese and silicon levels on the nutrient elements of immature sugarcane grown in sand culture

\begin{tabular}{c|c|c|c|c|c|c}
\hline \multirow{2}{*}{ Treatment } & \multicolumn{5}{|c|}{ Content of element in cane plant on percent-dry-weight basis for- } \\
\cline { 2 - 7 } & $\mathrm{N}$ & $\mathrm{P}$ & $\mathrm{K}$ & $\mathrm{Ca}$ & $\mathrm{Mg}$ & $\mathrm{S}$ \\
\hline $\mathrm{Mn}:$ & & & & & & \\
0 & 1.52 & 0.37 & 3.18 & 0.46 & 0.29 & 0.31 \\
10 & 1.43 & .39 & 3.21 & .41 & .28 & .30 \\
100 & 1.49 & .39 & 3.18 & .36 & .30 & .26 \\
$\mathrm{Si}:$ & & & & & & .26 \\
0 & 1.58 & .43 & 3.38 & .49 & .31 & .36 \\
50 & 1.47 & .37 & 3.04 & .40 & .29 & .26 \\
500 & 1.39 & .34 & 3.16 & .35 & .27 & .25 \\
\hline
\end{tabular}

1 Mean of all treatments at element and level indicated.

\section{SUGAR AND PROTEIN CONTENT OF LEAF AND MERISTEM}

Total ketose content was highest in plants receiving 500 p.p.m. of Si at the 10- and 100-p.p.m. levels of Mn (table 5). This was true for both leaf and meristem samples. Leaf-sucrose content was suppressed by high $\mathrm{Si}$ at zero $\mathrm{Mn}$, but was greatly increased by the 500-p.p.m. Si treatment when Mn was high. Meristem sucrose was increased by high Si at all Mn levels. High increased sucrose in both leaf and meristem at the 50- and 500-p.p.m. concentrations of $\mathrm{Si}$. The same high-Si $\times$ high-Mn treatment which severely stunted growth yielded the maximum sucrose values recorded. Leaf fructose was generally increased by 500 p.p.m. $\mathrm{Si}$, particularly when $\mathrm{Mn}$ was low. This sugar was not as greatly affected by nutrient variables inmeristem.

Perhaps the most striking effect of this study was the high leaf-protein content recorded among all plants receiving 500 p.p.m. of Si. This response was least evident at the 10 -p.p.m. level. High $\mathrm{Mn}$, as compared with zero 
TABLE 5.-Mean values ( $m g . / g . d r y$ weight) for main effects and first-order interactions, summarizing sugar and protein contents of immature sugarcane supplied with variable manganese and silicon in sand culture ${ }^{1}$

Leaf sugars

\begin{tabular}{|c|c|c|c|c|c|c|c|c|c|c|c|c|}
\hline \multirow{2}{*}{ Si } & \multicolumn{4}{|c|}{ Total Ketose } & \multicolumn{4}{|c|}{ Sucrose } & \multicolumn{4}{|c|}{ Fructose } \\
\hline & $\mathbf{M} \mathbf{n}_{0}$ & $\mathbf{M n}_{\mathbf{1 0}}$ & $\mathbf{M n}_{100} \mid$ & Mean & $\mathbf{M} \mathbf{n}_{\mathbf{o}}$ & $\mathrm{Mn}_{10}$ & $\mathbf{M n}_{100}$ & Mean & $\mathrm{Mn}_{0}$ & $\mathbf{M n}_{10}$ & $\mathbf{M n}_{200}$ & Mean \\
\hline 0 & 76.4 & 76.8 & 81.9 & 78.3 & 44.8 & 33.1 & 36.8 & 38.2 & 31.6 & 40.7 & 45.1 & 39.1 \\
\hline 50 & 91.2 & 88.7 & $|113.6|$ & 97.8 & 44.9 & 47.8 & 62.5 & 51.7 & 46.3 & 40.9 & 51.1 & 46.1 \\
\hline 500 & 76.7 & 105.6 & 128.7 & 103.7 & 28.8 & 44.5 & 73.6 & 48.9 & 47.8 & 61.1 & \begin{tabular}{|l|}
54.9 \\
\end{tabular} & 54.6 \\
\hline Mean & 81.4 & 90.4 & 108.1 & & 39.5 & 41.8 & 57.6 & & 41.9 & 47.6 & 50.4 & \\
\hline
\end{tabular}

Meristem sugars

\begin{tabular}{|c|c|c|c|c|c|c|c|c|c|c|c|c|}
\hline \multirow{2}{*}{$\mathbf{S i}$} & \multicolumn{4}{|c|}{ Total Ketose } & \multicolumn{4}{|c|}{ Sucrose } & \multicolumn{4}{|c|}{ Fructose } \\
\hline & $\mathbf{M n}_{0}$ & $\mathbf{M n}_{10}$ & $\mathbf{M n}_{\mathbf{1 0 0}}$ & Mean & $\mathbf{M n}_{0}$ & $\mathbf{M n}_{10}$ & $\mathbf{M n}_{\mathbf{2 0 0}}$ & Mean & $\mathbf{M n}_{\mathbf{0}}$ & $\mathbf{M n}_{10}$ & $\mathbf{M n}_{\mathbf{1 0 0}}$ & Mean \\
\hline 0 & 198 & 191 & 172 & 187 & 11.1 & 8.5 & 11.5 & 10.4 & 187 & 184 & 160 & 177 \\
\hline 50 & 218 & 209 & 209 & 212 & 9.3 & 9.6 & 16.6 & 11.8 & 208 & 203 & 193 & 201 \\
\hline 500 & 208 & 229 & 255 & 231 & 18.1 & 15.1 & 64.8 & 32.7 & 189 & 214 & 190 & 198 \\
\hline Mean & 208 & 209 & 212 & & 12.8 & 11.1 & 30.9 & & 195 & 200 & 181 & \\
\hline
\end{tabular}

Prolein

\begin{tabular}{|c|c|c|c|c|c|c|c|c|c|}
\hline \multirow{2}{*}{$\mathbf{S i}$} & \multicolumn{4}{|c|}{ Leaf protein } & \multicolumn{5}{|c|}{ Meristem protein } \\
\hline & $\mathbf{M n} \mathbf{n}_{0}$ & $\mathbf{M n}_{\mathbf{2 0}}$ & $\mathbf{M n}_{200}$ & Mean & $\mathbf{S i}$ & $\mathbf{M n}_{0}$ & $\mathbf{M n}_{\mathbf{2 0}}$ & $\mathbf{M n}_{100}$ & Mean \\
\hline $\mathbf{0}$ & 3.12 & 3.34 & 4.08 & 3.51 & 0 & 12.5 & 14.9 & 13.0 & 13.5 \\
\hline 50 & 3.71 & 3.81 & 6.39 & 4.64 & 50 & 15.1 & 15.5 & 13.6 & 14.7 \\
\hline 500 & 10.45 & 4.25 & 11.57 & 9.09 & 500 & 11.8 & 12.6 & 7.7 & 10.7 \\
\hline Mean & 5.76 & 4.13 & 7.35 & & Mean & 13.1 & 14.3 & 11.4 & \\
\hline
\end{tabular}

1 Each figure represents the computed mean of 5 replicates.

$\mathrm{Mn}$, increased protein more at the 0 and 50-p.p.m. Si levels. Meristem protein content reflected a generally reverse response to high $\mathrm{Si}$.

\section{Enzyme Activity}

Each of the three phosphatases measured were generally suppressed by increasing concentrations of both $\mathrm{Si}$ and $\mathrm{Mn}$ (table 6). A similar effect was exerted by the two elements upon starch phosphorylase. Thus, the greatly retarded growth caused by high $\mathrm{Si}$ and high $\mathrm{Mn}$ was accompanied by 
marked suppression of both starch phosphorylase and the phosphatases.

High Si greatly retarded leaf amylase, particularly so when Mn was also high. Medium $\mathrm{Mn}$, as compared with $0 \mathrm{Mn}$, stimulated amylase, but high $\mathrm{Mn}$ retarded the enzyme at the 50- and 500-p.p.m. levels of Si. At zero Si, both medium and high Mn stimulated amylase. Peroxidase was not greatly affected by any treatment.

Polyphenoloxidase was markedly affected by both $\mathrm{Mn}$ and $\mathrm{Si}$ in meristem (table 7). Mn at 10 p.p.m., as compared with zero p.p.m., increased

TABLE 6.-Mean values for main effects and first-order interactions, in units of specific activity, for leaf enzymes of immature sugarcane supplied with variable manganese and silicon in sand culture 1

\begin{tabular}{|c|c|c|c|c|c|c|c|c|c|c|c|c|}
\hline \multirow{2}{*}{ si } & \multicolumn{4}{|c|}{ B-glyecrophosphatase } & \multicolumn{4}{|c|}{$A T P$-ase } & \multicolumn{4}{|c|}{ Gircose-1-phosphataso } \\
\hline & $\mathbf{M} \mathbf{n}_{0}$ & $\mathbf{M n}_{\mathbf{1 0}}$ & $\mathbf{M n _ { 1 0 0 }}$ & Mean & $\mathbf{M n} \mathbf{0}$ & $\mathbf{M n}_{30}$ & $\mathbf{M} \mathbf{n}_{100}$ & Mean & $\mathbf{M} \mathbf{n}_{0}$ & $\mathbf{M n}_{\mathbf{n}}$ & $\mathbf{M n}_{100}$ & Mean \\
\hline 0 & 18.6 & 14.2 & 12.2 & 15.0 & 13.1 & 10.4 & 6.6 & 10.0 & 24.9 & 15.8 & 15.1 & 18.6 \\
\hline 50 & 12.9 & 15.1 & 8.4 & 12.1 & 9.8 & 9.1 & 4.9 & 7.9 & 18.4 & 16. & 11.6 & 15.4 \\
\hline 500 & 11.4 & 12.1 & 9.9 & 11.1 & 7.2 & 7.3 & 5.0 & 6.5 & 14.7 & 15.7 & 13.2 & 14.5 \\
\hline Mean & 14.3 & 13.8 & 10.2 & & 10.1 & 8.9 & 5.5 & & 19.3 & 15.8 & 13.3 & \\
\hline \multirow{2}{*}{ Si } & \multicolumn{4}{|c|}{ Starch phosphor ylase } & \multicolumn{4}{|c|}{ Amylase } & \multicolumn{4}{|c|}{ Peroxidaso } \\
\hline & $\mathbf{M n}$ 。 & $\mathbf{M n}_{\mathbf{1 0}}$ & $\mathbf{M n}_{\mathbf{1 0 0}}$ & Mean & $\mathbf{M n} \mathbf{n}_{\mathbf{0}}$ & $\mathbf{M n}_{\mathbf{3 0}}$ & $\mathbf{M n}_{100}$ & Mean & $\mathbf{M n}_{0}$ & $\mathbf{M n}_{\mathbf{3}}$ 。 & $\mathbf{M n}_{\mathbf{1 0 0}}$ & Mean \\
\hline $\mathbf{0}$ & 16.0 & 15.8 & 10.5 & 14.1 & 804 & 1,205 & 1,253 & 1,087 & 101 & 88 & 81 & 80 \\
\hline 50 & 16.5 & 13.8 & 11.6 & 13.9 & 956 & 1,298 & 795 & 1,016 & 75 & 70 & 69 & 71 \\
\hline 500 & 13.1 & 13.2 & 9.5 & 11.9 & 776 & 819 & 570 & 722 & 92 & 95 & 79 & 88 \\
\hline Mean & 15.2 & 14.2 & 10.5 & & 845 & $\mid 1,107$ & 873 & & 89 & 84 & 76 & \\
\hline
\end{tabular}

1 Each figure represents the computed mean of 5 replicates.

activity at all Si levels. High $\mathrm{Mn}$ induced no further increases at 0 and 50 p.p.m. Si, and greatly retarded the enzyme at 500 p.p.m. Si. Increasing Si concentrations suppressed oxidase activity at all levels of $\mathrm{Mn}$.

Invertase was severely suppressed by high Si at all Mn levels. High Mn likewise retarded invertase, the effect being most pronounced when Si was low. Neither beta-glycerophosphatase nor amylase was appreciably affected by $\mathrm{Mn}$ or $\mathrm{Si}$ in meristem.

\section{DISCUSSION}

The uptake of $\mathrm{Mn}$ by the immature sugarcane plant was definitely suppressed by increasing Si levels in the nutrient medium. As the Mn content 
of the plant dropped, silicon content rose. Thus, there appears to be an inverse relationship between $\mathrm{Mn}$ and $\mathrm{Si}$ in the cane plant.

As was stated before, $\mathrm{Mn}$ uptake is depressed by increasing Si levels in the nutrient medium. However, the converse does not hold, for Si uptake in the cane plant does not appear to be suppressed with increasing $\mathrm{Mn}$ levels in the nutrient medium. In fact, Si levels in the leaf blade increased as $\mathrm{Mn}$ levels were raised (table 2). This increase became more apparent as the Si levels were increased. It thus appears that when the cane plant is

TABus 7.-Mean values for main effects and first-order interactions, in units of specific activity, for meristem enzymes of immature sugarcane supplied with variable manganese and silicion in sand cullurel

\begin{tabular}{|c|c|c|c|c|c|c|c|c|}
\hline \multirow{2}{*}{$\mathbf{S i}$} & \multicolumn{4}{|c|}{ R-glycerophosphatase } & \multicolumn{4}{|c|}{ Polyphenol oxidase } \\
\hline & $\mathbf{M n} \mathbf{n}_{\mathbf{0}}$ & $\mathrm{Mn}_{20}$ & $\mathbf{M} \mathbf{n}_{200}$ & Mean & $\mathbf{M} \mathbf{n}_{0}$ & $\mathbf{M n}_{10}$ & $\mathbf{M n}_{100}$ & Mean \\
\hline $\begin{array}{r}0 \\
50 \\
500\end{array}$ & $\begin{array}{l}14.3 \\
11.8 \\
11.7\end{array}$ & $\begin{array}{l}15.2 \\
14.2 \\
12.5\end{array}$ & $\begin{array}{l}13.9 \\
11.2 \\
14.9\end{array}$ & $\begin{array}{l}14.5 \\
12.4 \\
13.0\end{array}$ & $\begin{array}{r}12.3 \\
11.6 \\
9.5\end{array}$ & $\begin{array}{l}24.3 \\
19.5 \\
12.9\end{array}$ & $\begin{array}{r}21.3 \\
15.3 \\
4.9\end{array}$ & $\begin{array}{r}19.3 \\
15.5 \\
9.1\end{array}$ \\
\hline Mean & 12.6 & 13.9 & 13.3 & & 11.1 & 18.9 & 13.8 & \\
\hline \multirow{2}{*}{ Si } & \multicolumn{4}{|c|}{ Invertase } & \multicolumn{4}{|c|}{ Amylase } \\
\hline & $\mathbf{M} \mathbf{n}_{0}$ & $\mathbf{M} \mathbf{n}_{20}$ & $\mathbf{M n}_{100}$ & Mean & $\mathbf{M} \mathbf{n}_{0}$ & $\mathbf{M} \mathbf{n}_{30}$ & $\mathbf{M n}_{100}$ & Mean \\
\hline $\begin{array}{r}0 \\
50 \\
500\end{array}$ & $\begin{array}{l}7.7 \\
3.6 \\
2.0\end{array}$ & $\begin{array}{l}4.9 \\
3.5 \\
2.8\end{array}$ & $\begin{array}{l}3.9 \\
2.6 \\
1.2\end{array}$ & $\begin{array}{l}5.5 \\
3.2 \\
2.0\end{array}$ & $\begin{array}{l}113 \\
100 \\
138\end{array}$ & $\begin{array}{l}112 \\
107 \\
109\end{array}$ & $\begin{array}{l}125 \\
124 \\
132\end{array}$ & $\begin{array}{l}117 \\
110 \\
126\end{array}$ \\
\hline Mean & 4.4 & 3.7 & 2.6 & & 117 & 109 & 127 & \\
\hline
\end{tabular}

1 Each figure represents the computed mean of 5 replicates.

faced with an excessive supply of $\mathrm{Mn}$, it attempts to compensate by increasing its Si uptake.

It was interesting to note that the suppression of leaf phosphatases by increasing $\mathrm{Si}$ and $\mathrm{Mn}$ was accompanied by a general increase of sucrose. $\mathrm{A}$ similar phosphatase-sucrose relationship has been observed previously ( 1 , 2) and seems to appear in response to different types of treatments. It has also been induced in cane with specific phosphatase inhibitors $(3,8)$. We feel that the suppression of phosphatase makes possible a more favorable supply of phosphorylated precursors needed for sucrose synthesis.

High $\mathrm{Mn}$ and Si likewise induced maximum sucrose content in meristem, but here the suspected enzyme is invertase rather than phosphatase. In- 
vertase activity was almost nonexistant in the presence of high $\mathrm{Mn}$ and Si. Curiously, no striking differences in meristem fructose were apparent as a consequence of variable invertase activity.

Manganese serves as an in vitro activator of both invertase (5) and amylase (4) of sugarcane. The zero-p.p.m. Mn treatment was apparently insuficient for maximum leaf amylase action during the present study, but in meristem neither amylase nor invertase were stimulated by added Mn. A very minute quantity of $\mathrm{Mn}$ is needed for activation, less than $1 \mu \mathrm{mole} / \mathrm{ml}$. under in vitro conditions, and this need may have been satisfied in meristem by differential accumulation of contaminate $\mathrm{Mn}$.

Polyphenol oxidase showed a greater sensitivity to variable $\mathrm{Mn}$ and $\mathrm{Si}$ than any other enzyme assayed. There was no inkling that this should have been the case, yet the fact that both invertase and protein content were affected by these same treatments brings up several possibilities.

A first consideration is that $\mathrm{Mn}$ and Si have interfered somehow with mechanisms of auxin and protein synthesis. Gordon and Paleg (18) published evidence that polyphenol oxidase is essential in the following sequence for IAA synthesis:

\section{Phenols $\frac{\mathrm{O}_{2}}{\text { Oxidase }}$ Quinones \\ Quinone + Tryptophan___ Indolepyruvic acid_IAA}

They found that IAA formation was stimulated by the addition of catechol to mungbean preparations. The reverse effect would logically be achieved by inhibiting polyphenol oxidase. Perhaps the excessive stunting of plants subjected to high $\mathrm{Si}$ and $\mathrm{Mn}$ was mediated in part by a curtailed auxin mechanism.

A second consideration is the fact that both oxidases and auxins are becoming increasingly implicated in protein formation and in the synthesis of specific enzymes. IAA and 2,4-dichlorophenoxyacetic acid have been shown to enhance the incorporation of $\mathrm{C}^{14}$-labelled glycine into protein in excised pea shoots (16). Sacher and coworkers $(27,28)$ havel stimulated invertase formation in sugarcane with IAA and naphthalene acetic acid (NAA). Other workers have shown that gibberellic acid increases the synthesis or activity of amylase (23,24), and maltase (29). As noted earlier, a marked increase of leaf protein was observed among plants receiving high $\mathrm{Si}$, which again may implicate a high $\mathrm{Si}$ effect upon an auxin mechanism.

Oxidases appear to be involved in auxin destruction as well as auxin synthesis. Peroxidase is regarded as the effective component of IAA oxidase (25). Although peroxidase did not vary greatly during the present study, 
earlier work in Puerto Rico revealed that foliar IAA application to sugarcane greatly stimulated leaf peroxidase activity (2). Halevy (19) and and Monselise and Halevy (22) found that growth-retarding compound "Amo-1618" increased peroxidase in seedlings, and they concluded that growth retardants influence auxin level in plant tissues by promoting auxin destruction.

A third consideration is the probability that invertase is one of the principle enzymes affected by the auxin-regulated synthesis of protein. Glasziou and coworkers $(27,28)$ feel that this is so. The severe decline of invertase activity among plants receiving high $\mathrm{Si}$ and $\mathrm{Mn}$ might thus reflect a decreased capacity to synthesize invertase rather than direct action upon the catalyst itself.

\section{SUMMARY}

Sugarcane variety M. 336 was grown in solution culture for 3 months under $3 \mathrm{Mn}$ levels (0,10, and 100 p.p.m.) and $3 \mathrm{Si}$ levels $(0,50$, and 500 p.p.m.) to study the influence of various levels of $\mathrm{Mn}$ and $\mathrm{Si}$ on growth, nutrient composition, and enzyme and sugar activity. The uptake of $\mathrm{Mn}$ by the immature sugarcane plant was definitely suppressed by increasing $\mathrm{Si}$ levels in the nutrient medium. As the $\mathrm{Mn}$ content of the plant dropped $\mathrm{Si}$ content increased. However, the converse did not hold, for when the cane plant was faced with an excessive supply of $\mathrm{Mn}$, it attempted to compensate by increasing its Si uptake.

High-Si $\times$ high-Mn treatment severely stunted growth, but yielded the maximum sucrose values recorded. Leaf-protein content was highest with all plants at the high $\mathrm{Si}$ level, but meristem protein reflected a reverse response. The greatly retarded growth caused by high $\mathrm{Si}$ and high $\mathrm{Mn}$ was accompanied by marked suppression of both starch phosphorylase and the phosphatases. Polyphenol oxidase showed a greater sensitivity to variable $\mathrm{Mn}$ and Si than any other enzyme assayed. Possible roles of $\mathrm{Mn}$ and $\mathrm{Si}$ in the mechanisms of auxin and protein synthesis are discussed.

\section{RESUMEN}

La variedad de caña de azúcar M. 336 se cultivó por 3 meses en una solución a tres niveles de $\mathrm{Mn}(0,10$ y 10 p.p.m.) y tres de $S i(0,50$ y 500 p.p.m.) para estudiar el efecto de diversos niveles de $\mathrm{Mn}$ y $\mathrm{Si}$ sobre el crecimiento, la composición de los nutrimentos, y la acción de las enzimas y del azúcar. La absorción de Mn por la planta de caña inmadura se suspendió al aumentarse los niveles de $\mathrm{Si}$ en el medio nutritivo. Según bajaba el contenido de $\mathrm{Mn}$ aumentaba el de Si. Sin embargo, lo contrario no tuvo lugar, ya que al confrontarse la planta con una cantidad excesiva de Mn trató de compensarlo absorbiendo más $\mathrm{Si}$. 
El tratamiento con niveles altos de Si $\mathrm{X}$ niveles altos de $\mathrm{Mn}$ impidieron severamente el crecimiento, aunque produjeron los valores máximos de sacarosa que se registraron. El contenido de proteína en la hoja fue mayor en las plantas que recibieron un alto nivel de $\mathrm{Si}$, pero en el meristemo sucedió lo contrario. La excesiva retardación del crecimiento causada por el alto tratamiento con $\mathrm{Si} \mathrm{y} \mathrm{Mn} \mathrm{fue} \mathrm{acompañada} \mathrm{de} \mathrm{una} \mathrm{decidida} \mathrm{supre-}$ sión, tanto de la fosforilasa de almidón como de las fosfatasas. Entre las enzimas que se probaron, la oxidasa de polifenol reveló una mayor sensitividad a los niveles variables de $\mathrm{Mn}$ y $\mathrm{Si}$. Se discute la posible función que desempeñan el Mn y el Si en el mecanismo de la síntesis de la auxina y la proteína.

\section{LITERATURE CITED}

1. Alexander, A. G., Sucrose-enzyme relationships in immature sugarcane as affected by varying levels of nitrate and potassium supplied in sand culture, J. Agr. Univ. P.R. 48(3): 165-231, 1964.

2. - Changes in leaf sugar content and enzyme activity of immature sugarcane following foliar application of indole-3 acetic acid, 2,4-dichlorophenoxyacetic acid, and maleic hydrazide, J. Agr. Univ. P.R. 49(1): 1-34, 1965.

3. - Induction of varying sugar level in leaves of immature sugarcane by use of acid phosphatase inhibition, J. Agr. Univ. P. R. 49(1): 35-59, 1965.

4. - Hydrolytic proteins of sugarcane: The acid phosphatases, J. Agr. Univ. P.R. 49(2): 204-28, 1965.

5. - Hydrolytic proteins of sugarcane: The acid invertases, J. Agr. Univ. P.R. 49(3): 287-307, 1965.

6. - - Hydrolytic proteins of sugarcane: Amylase, J. Agr. Univ. P.R. 49(3): 308$24,1965$.

7. - The biosynthesis of starch in sugarcane. Proc. I.S.S.C.T. 12th. Cong. 1965. (In press)

8. - Effects of tungsten and molybdenum upon sucrose content and hydrolytic enzymes of immature sugarcane, J. Agr. Univ. P.R. $50,1966$.

9. —, The oxidizing enzymes of sugarcane: Peroxidase, J. Agr. Univ. P. R. $50(1)$ : 36-52, 1966.

10. - - The oxidizing enzymes of sugarcane: Tyrosinase, J. Agr. Univ. P.R. $50(2)$ : 113-30, 1966.

11. Ayres, A., Cane growth studies at Waipo Substation; Experiment E; Haw. Plant. Rec. 84: 445-60, 1930.

12. Ballard, S. S., The spectographic study of the distribution of mineral elements in sugarcane, Haw. Plant. Rec. 44: 183-6, 1940.

13. Cardini, C. E., Leloir, L. F., and Chiriboga, J., The biosynthesis of sucrose, $J$. Biol. Chem. 214: 149-55, 1955.

14. Clements, H. F., Factors determining the response of sugarcane to calcium carbonate in hydrol humic latosols, Proc. Int. Soc. Sugar Cane Tech., 11th Cong. 140-61, 1963.

15. - Effects of silicate on the growth and leaf freckle of sugarcane Proc. Int. Soc. Sugar Cane Tech., 12th. Cong, (In press), 1965.

Fang, S. C. and Te Chang Yu, Influence of auxins on in vitro incorporation of glycine-C ${ }^{14}$ in pea shoot proteins, Plant. Physiol. 40(2): 299-303, 1965. 
17. Gile, P. L. and Smith, J. G., Colloidal silica and the efficiency of phosphates, $J$. Agr. Res. 81: 247-60, 1925.

18. Gordon, S. A. and Paleg, L. G., Formation of auxin from tryptophan through action of polyphenols, Plant Physiol. 36: 838-45, 1961.

19. Halevy, A. H., Inverse effect of gibberelin and Amo-1618 on growth, catalase, and peroxidase activity in cucumber seedlings, Experentia. 18: 74-6, 1962.

20. Kuijper, J., Archief. Suikerind. Ned.-Indiec. 28: 528-56, 1915.

21. Lanning, F. C., Ponnaiya, B. W. X., and Crumpton, C. F., The chemical nature of silica in plants, Plant Physiol. 38: 339-43,1958.

22. Monselise, S. P., and Halevy, A. H., Effects of gibberellin and Amo-1618 on growth, dry matter accumulation, chlorophyll content, and peroxidase activity of citrus seedlings, Amer. J. Bot. 49: 409-12, 1962.

23. Paleg, L. G., Physiological effects of gibberellic acid: 1. On carbohydrate metabolism and amylase activity of barley endosperm. Plant Physiol. 35: 293-9, 1960.

24. Paleg, L. G., Physiological effects of gibberellic acid. II, On starch hydrolyzing enzymes of barley endosperm, Plant Physiol. 86: 829-37, 1961.

25. Ray, P. M., Destruction of auxin, Amer. Rev. Plant. Physiol. 9: 81-118, 1958.

26. Roe, J. R., A colorimetric method for the determination of fructose in blood and urine, J. Biol. Chem. 107: 15-22, 1934.

27. Sacher, J. A. and Glasziou, K. T., Regulation of invertase levels in sugarcane by an auxin-carbohydrate mediated control system, Biochem. and Biophys. Res. Commun. 8(4): 280-2, 1962.

28. —, Hatch, M. D., and Glasziou, K. T., Regulation of invertase synthesis in sugarcane by an auxin and sugar-mediated control system, Physiolog. Plantarum 16: 836-42, 1963.

29. Simpsom, G. M. and Naylor, J. M., Dormancy studies in seed of Avena fatua. III, A relationship between maltase, amylase, and gibberellin. Can. J. Bot. 40: 1659-73, 1962.

30. Sutherland, E. W., Cori, C. F., Haynes, R., and Olsen, W. S., Purification of the hyperglycemic-glycogenolytic factor from insulin and from gastric mucosa, J. Biol. Chem. 180: 825-37, 1949.

31. Van Dillewijn, C., Botany of Sugarcane. The Chronica Botanica Co., Waltham, Mass., 1952.

32. Villiers De, and $D$ 'hotman, $O$., Soil rejuvenation with crushed basalt in Mauritius, 1. The International Sugar J., 68: 363-4, 1961. 